\title{
Patterns of Vocational Education Partnership in the Era of Decentralization
}

\author{
Muhammad Yahya ${ }^{\mathrm{a}, 1}$, Yasdin ${ }^{\mathrm{b}, 2}$ \\ ${ }^{a}$ State University of Makassar, Faculty of Engineering, Makassar, INDONESIA \\ ${ }^{\mathrm{b}}$ Postgraduate Yogyakarta State University \\ Technology and Vocational Education Program, Yogyakarta, INDONESIA \\ 1yahyapto@yahoo.co.id, ${ }^{2}$ yasdinptkuny@gmail.com
}

\begin{abstract}
This article aims to explain the management of vocational education, especially partnerships with industry in the era of regional autonomy and decentralization of education. Delegation of authority from the central government requires local governments to manage the education sector, especially vocational education. In fact, as a vocational secondary education are often prepared to work hard to find industry partners or cooperation partner in the absorption of graduates because it is not supported of policy pro vocational education. Local governments are still too pinned their hopes on the privately run industrial absorbent vocational education graduates. One of the policies that can be done to overcome this problem is to optimize the role of Badan Usaha Milik Daerah (BUMD) as a new industry to absorb the graduates of vocational education through a partnership. This partnership requires the support of the executive and legislative sides.
\end{abstract}

Index Terms - patterns, partnership, vocational education, decentralization

\section{Introduction}

Vocational education has gained the attention of the government. Vocational education gets a share of development compared to other education. As per the strategic plan of the Ministry of Education and Culture 2009-2014, vocational education will be expanded to reach $70 \%$ of the entire quantity of existing schools or in other words the ratio of vocational schools and public schools will reach 70: 30. This policy appears like two sides of a coin which has positive and negative impacts. An increasing number of vocational high schools (SMK) should be proportional to the availability of prospective workers because basically vocational education is an education that prepares students to work.

Vocational technical education had been emphasized in Malaysia education system since before the independence era. It is organized at all the three levels of education in the country: Basic or primary level, secondary level, and tertiary level [1]. Vocational Technical Education is any kind of education which has the main purpose of preparing one for employment in recognized occupation. The foundation of vocational technical education is based on philosophy which was mainly established for self- employment and selfreliance of the individual(s) who partake in it [2].

An increasing number of vocational schools will have a negative impact if it is not followed by job growth. Increasing the number of students in vocational also directly proportional to the number of graduates to be produced.
Thus, the number of potential workforce also increased since the graduates of vocational graduates are prioritized into labor in a particular area of expertise. An increasing number of vocational schools that are not accompanied by growth in employment as well as deliberately creating new unemployments. Vocational education is an economic education as it geared to the needs of the job marked and thus contributed to the national economic growth [3]. Technical education and vocational and training was found effective. It was responsive to the needs of industry, meets expectations of the students and was accepted by the employer. The graduates have necessary skills for further study and employment [4].

\section{Vocational Education Partnership}

ASEAN Economy Community (AEC) has been anticipated by the government through a program that is set up relevant institutions. The SMK students have been encouraged to attend skill competition in the national level, asian level (Asian Skill Competition (ASC)), and the international level (World Skill competition (WSC). AEC is a political policy that would encourage ASEAN competitiveness in the world market. AEC is a stepping stone for Southeast Asian countries face the free market by 2020 almost the same as the AEC, the free market in 2020 will also be a threat to Indonesian workers, vocational school graduate, and vocational. According [5], the world of the $21^{\text {st }}$ century as an open world requires a competitive human resources. If local people are not able to compete the foreign workers, local people become jobless in their own country. Therefore, vocational graduates who will be enter the job market should be equipped with the skills to put up with more.

In the current global era, the various nations of the world have developed a knowledge-based economy, which requires the support of qualified human resources [6]. Mastery of skills and expertise in a particular field in a professional manner will improve the competitiveness of a person in entering the world of work in the era of the free market. According [7], the dimensions of the task of vocational and vocational opposite aspects; position, knowledge, attitudes, skills and rules. Only, mastery of skills and expertise must be adapted to technological developments and market demand. Strengthened partnerships will help alleviate poverty by reducing labor 
and skill mismatch by making labor pooling and matching available [8].

The addition portion of vocational education policy must necessarily be supported by all people, including government, from central to local levels, the private sector, and community. Poor policy formulation as opined by few individuals has little or no influence on the practice of functional vocational education [9].

...role in the organization of society education is still not optimal. People here are meant not only the parents and the surrounding community, but also the world of work and industry who will be users of the out put of existing educational institutions [10].

All these elements are the pillars of education and development. One of these elements which have an important role in promoting vocational education is the government, ranging from the central government, provincial, and district or city. The government will be in the spirit of the changes made including vocational education plan carefully to face the challenges.

Today, in the era of democracy, Indonesia embraced decentralization. Development planning is no longer carried unanimously by the central government. Decentralization is embodied in a policy known as regional autonomy. In this era, in the era of regional autonomy, the policy can be decided by the government at the local level because it has no delegation of authority from the central government. Regional autonomy, a synergistic policy. The central government has the right to regulate the master plan of the development of Indonesia. Indonesian master plan should be supported by the synergistic planning of local government as a policy contradictory between the center and regions will hamper the pace of development. The principle of local autonomy is done on all aspects of development.

Regional autonomy makes each region as development milestones. Regional autonomy is also done not only carried out in accordance with the paradigm of infrastructure development but more than that. Regional autonomy should also boost the development of human resources. One of the efforts that should be done is to fix the education system but still in accordance with the ideals of national education. As part of the national education system, vocational education is the education system that must be considered for each region developed in the era of regional autonomy.

This view suggests that local autonomy in education should be directed to sustainable regional development without intervention from the center. However, that does not mean to deviate from the master plan of the central government. Vocational education as one of the Indonesian education system should be oriented towards the empowerment of graduates in employment as an effort to reduce unemployment. Therefore, the development of vocational education should pay attention to four things: (a) industrial relations, (b) technological changes, (c) the organization of work, and (d) formation of the competence and the four components must interact with each other [11].

Allows local governments to formulate policies across sectors and institutions for vocational education. Employment or the world of work and unemployment issues are closely related to the education of honesty can be overcome with foresight in formulating government policy. Law Number 32 Year 2004 regarding Regional Government delegated authority from central government to local governments so lets make creations, innovations, and improvements in regional development efforts, including in the field of education.

Education policy issued by the local government is still too general and not divided into policies that are tailored to the type of education. Especially for vocational education, has not appeared in a particular policy pro employment. Field work, the world of work, and unemployment is a huge challenge local government decentralization. According [12] era of regional autonomy, it is possible to spawn local governments and government policies in education, including vocational education in relation to employment, the workforce, and unemployment.

Regional autonomy remains piecemeal including vocational education planning area. Most areas have not been able to synergize and cross-sectorial development agencies to support the sustainability of vocational education. As an autonomous region, the local government may think of the function linkage between agencies to support the implementation of vocational education. In the era of regional autonomy, one of the policies that have appeared in the area is the establishment of the Regional Have Enterprises (enterprises) which was established to encourage and promote the development and regional economy. Enterprise established in profit oriented local governments without thinking about the direction of development of human resources.

Established Regional Owned Enterprises (BUMD) does not involve the community in the management significantly, including public schools in these vocational education students. The Regional Owned Enterprises should absorb labor from graduates of the SMK. Not only absorb labor, local governments can also design a pair of industrial enterprises into vocational education. Students can make enterprises as the industry practice to the field of their expertise. Making enterprises as an alternative industry to forge vocational education and skills learners. Enterprises can serve as a new industry for internships or vocational school graduates or candidates for employment in accordance with the abilities and skills possessed. However, it must be adjusted between enterprises with expertise characteristic of students. According [13], educational institutions and the world of work can offer services to each other is mutually beneficial to both parties. Students can take advantage of the world of work as a skilled workforce, educational institutions have the opportunity to run a program on the job learning.

Enterprises planning must be done accurately. Therefore, management of enterprises should be prepared carefully and comprehensively. Local governments will be able to synchronize with the local vocational education policies enterprises. Government policy and education policy need political support. Such support should come from the executive and legislative branches in the area. Executive as policy implementers need legal form of the legislature. Legislative supports the executive in the form of defined rules. Regulations set out the legislative area involving several agencies will help the performance of the executive. Ratification of the regulations and policies of industrial enterprises as vocational education partner requires a clear and straightforward rules. 
...a complex interrelationship among interestgroups, politicians, educationist, bureaucrat and knowledge brokers [14]. Mentioned dimension, interest groups, politicians, educationist, bureaucrats and knowledge broker are interacted each other within sustainable TVET innovation processes. If one of these dimensions is absent, we speak of a limited innovation pattern (LIP). TVET dialogue at national or international level is only based on the dialogue between policy and the social partners represented by trade, industry and craft the potentials and development existing all over the world an in all countries as gigantic network of universities with all their domain specific colleges and institutes these potential not used in an incomplete TVET dialogue [15].

Synergize enterprises with vocational education as an industry partner can be realized as effectively and efficiently as possible because the region has regional owned enterprises. Enterprises have been established in various sectors of the economy and areas. Only, the development of inter-regional establishment of public enterprises is not the same depending on the policy of each area. Each province is different from one another. Regional owned enterprises between the cities are different from one another. When comparing the development of the establishment of enterprises, urban areas have more regional owned enterprises compare to the district. This is because, the urban sector is more vital than the district.

Implementation of policies geared to changes in certain things. Implementation of government policy in favor of vocational education through established enterprises. On the establishment and management of enterprises, local governments are expected to become the industry to absorb the graduates of vocational alternatives so that graduates of vocational education is not just pinning their hopes on a managed private industry alone. Managed enterprises that local governments are expected to be new jobs for graduates of vocational education. In addition, enterprises are also expected to be a new practice for students of vocational education so that they can become skilled workforce that can compete in the era of the AEC and the free market in 2020.

\section{Conclusions}

In the implementation of government policy in managing enterprises needs to study aspects of planning and management for the purpose of development of vocational education, especially education. In Nigeria, government intervention in providing human and infrastructural resources gives vocational technical education a facelift philosophically, sociologically and psychologically [2].

The study was conducted to determine the seriousness of the government in program for the development of other areas, namely the establishment of enterprises associated with the development of local kejurun education. If these aspects are considered less then needs to be improved in practice. It should be based on the formulation of policies issued by the government so that the desired objectives can be achieved. Management of industrial enterprises as an alternative and new jobs for vocational education will encourage economic growth and to support regional development.

Local government policy in encouraging enterprises as an alternative industries and new jobs is a labor policy.
Implementation of this policy should be supported by the readiness of human resources, managerial readiness, preparedness budget, infrastructure readiness, and commitment to implementing that local government as policy makers, public as service users, community representatives through the legislature as policy advocates. Realization of industrial enterprises as an alternative would be a new job, with the support of all walks of life will encourage the creation of employment opportunities for all graduates of vocational education. In addition, enterprises will be a new practice for students of SMK before getting into the world of work. This will encourage vocational graduates into the labor candidates who are ready to compete with other workers, including foreign workers who will go to Indonesia in the era of the AEC and the free market in 2020.

The realization of industrial enterprises as an alternative to going to play a role in the reduction of unemployment. Enterprises will be the new jobs that are ready to accommodate graduates of vocational education. If the local government's role is not optimal in view of the threat of the AEC and the free market in 2020, almost certainly the local government will deal with the problem of unemployment. One way people can do to fight unemployment is the optimization of the role of vocational education through the realization of industrial enterprises into alternative. So, if unemployment is higher then the gap will be wider and the public welfare would be lower. Two things that will cause turmoil in the midst of society.

The employment policy is closely associated with local government policies and education policies, especially policies for vocational education. Realizing industrial enterprises into alternative and new jobs require a wellplanned policy formulation. The program is expected to overcome the problems that have implications for vocational education on employment, unemployment, social inequality, social welfare, and social unrest.

\section{References}

[1] M. Afwan, Leadership on technical and vocational education in community college. Journal of Education Practise, Vol 4, No 21, 2123,2013

[2] O.O. Kennedy, Philosophical and sociological overview vocational technical education in Nigeria. International Journal of Academic Research in Business and Social Scienses, Vol 1, 167-175, 2011.

[3] J.F. Thompson, Foundation of vocational education. Englewood Cliffs, NJ: Prentice Hall, 1974.

[4] Z. Zaib and H.Harun, Leadership in technical and vocational education: toward excellence human capital. Journal of Education Practise, Vol 5, No 23, 132-135, 2014

[5] H.A.R. Tilaar, Membenahi pendidikan nasional. Jakarta: Rineka Cipta, 2009.

[6] Y.B. Irianto, Kebijakan pembaruan pendidikan: konsep, teori, dan model. Jakarta: PT RajaGrafindo Persada, 2011.

[7] W.S. Kusnawa, Dasar-dasar pendidikan vokasi \& kejuruan. Bandung: Alfabeta, 2013

[8] J. Lee, Partenership with industry for efficient and effective implementation of TVET. International Journal of Vocational Education and Training, 25, 39-56, 2010.

[9] E.O. Akpan, and C.F. Ido, Education policy in Nigeria: the bane of her practice of functional vocational education. Journal of Education and Practise, Vol 5, No19, 156-161, 2014. 
[10] Hasbullah, Otonomi pendidikan: kebijakan otonomi daerah dan implikasinya terhadap penyelenggaraan pendidikan. Jakarta: PT RajaGrafindo Persada, 2006.

[11] L. Field, Skilling Australia. Melbourne: Longman Cheshire, 1991.

[12] A. Syafruddin, Titik berat otonomi daerah pada daerah tingkat II dan perkembangannya. Bandung: Mandar Maju, 1991.

[13] J. Nizwardi, Pengembangan pendidikan teknologi dan kejuruan dan hubungan dengan dunia kerja. Jurnal pendidikan vokasi, Vol 1, No1, Februari 2011. PP 25-34, 2011.

[14] C.N Ozurumba and V.O Ebauara, Conceptual issues in politics of education. Journal of Education and Practise, 5, 194-200, 2014.

[15] P. Grollman and F. Rauner, International perspective on teachers and lecturers in technical and vocational education. Netherland: Springer, 2007. 